\title{
ANTIBIOTIC RESISTANCE IN ENTEROBACTERIACEAE ISOLATED FROM PORTUGUESE DELI MEATS
}

\author{
PAULA AMADOR, RUBEN FERNANDES, LUISA BRITO and CRISTINA \\ PRUDÊNCIO
}

\begin{abstract}
This study aimed to identify the presence of b-lactam-resistant bacteria in different types of Portuguese deli meats. The numbers of ampicillin resistant bacteria varied from negative in $25 \mathrm{~g}$ to $1.0 ¥ 10^{8}$ colony-forming units $\mathrm{g}$. Within 78 randomly selected $\mathrm{b}$-lactam-resistant bacteria, 24 different resistant phenotypes were found and $35.9 \%$ were multidrug resistant (MDR). The majority (87.2\%) of the isolates identified belonged to the Enterobacteriaceae family. The presence of the blaTEM gene was detected in 23 out of 67 isolates $(34.3 \%)$ and 16 of them presented MDR phenotypes. Four Klebsiella oxytoca isolates (6\%) harbored a gene for the CTX-M/OXY-type enzyme. The direct sequencing of their purified amplicons confirmed the presence of three types of blaoxy genes (bla oXY-1, bla $X_{X Y-2}$ and bla $O X Y-5$ ). These results suggest that without good hygienic practices, deli meats may act as a vehicle of transfer of blactam-resistant bacteria to the gastrointestinal tract of consumers.
\end{abstract}




\section{PRACTICAL APPLICATIONS}

In the current regulation on microbiological criteria for foodstuffs the test for Enterobacteriaceae is used as indicator of hygiene and contamination after processing. Nevertheless, the major concern for public health related to the presence of these bacteria in food is because of the emerging antibiotic resistance in this family, namely to b-lactams. Consequently, the ever-increasing consumption of ready-to-eat (RTE) food, can contribute to the spread of these resistant strains. In the present study different types of deli meats, sold at retail outlets in Portugal, presented levels of b-lactamresistant Enterobacteriaceae that suggested the lack of strict hygiene control measures in the food chain. Without good hygienic practices, the dissemination in the community of antibiotic resistance genes may assume serious proportions.

\section{INTRODUCTION}

Antimicrobial agents are widely used to prevent and to treat disease among food-producing animals and in some cases to improve feed utilization and growth rate (IFT 2006). Although providing for the health of foodproducing animals, these antimicrobial agents belong to the same antibiotic families used in human medicine and consequently similar resistance genes might emerge because of selective pressures applied in diverse environments (Aarestrup 1999; IFT 2006; Machado et al. 2008).

The emerging antibiotic resistance in the Enterobacteriaceae family is a significant problem that requires immediate attention. The increasing prevalence of antibiotic resistant Enterobacteriaceae, not only pathogenic but also commensal (nonclinical) bacteria, suggests that the community can act as a reservoir and that food can contribute to the spread of these resistant strains (Mesa et al. 2006). The most common mechanism of resistance among Enterobacteriaceae is the production of b-lactamases, chromosomally or plasmid encoded, which inactivate certain b-lactam antibiotics by hydrolyzing the b-lactam ring (Slama 2008; Smet et al. 2008). The persistent exposure of bacteria to a diversity of b-lactams has forced continuous production and mutation of b-lactamases, expanding their activity against the newly developed b-lactam antibiotics (Shah et al. 2004). These enzymes, named extendedspectrum b-lactamases (ESBLs), with more than 100 variants of different types, are most frequently reported as SHV, TEM, OXY and CTX-M types (Gniadkowski 2001).

Recent studies have alerted scientists to the worldwide presence of ESBLs in bacteria recovered from a diversity of animals and food products 
(Smet et al. 2008), with reports of the transfer of antibiotic resistance bacteria and their genes from animals to humans through the food chain (Angulo etal. 2004; Phillips et al. 2004). In fact, faecal contamination might occur during animal slaughter and/or processing, and the growth of the contaminating bacteria may occur during the product distribution and storage phases (IFT 2006; Simeoni et al. 2008). Moreover, lack of hygiene in food manipulation at retail outlets is also responsible for the spread of food pathogenic and commensal bacteria (Gevers et al. 2003; Macovei and Zurek 2007; Simeoni et al. 2008). In the current EU regulation on microbiological criteria for foodstuffs (Anon 2007) the test for Enterobacteriaceae has replaced the tests for coliforms that traditionally have been used as indicators of hygiene and contamination after processing. This is also valid for the evaluation of the microbiological quality of some RTE foods sampled at the point of sale (Gilbert et al. 2000). The awareness of antimicrobial resistance in commensals from food-producing animals lead the World Health Organization and the European Commission to consider their surveillance as one of the main priorities to control the spread of antimicrobial resistance from food animal products to humans (WHO 2000).

Many studies have been carried out on the spread of antimicrobial resistances perpetrated by bacteria isolated in clinical environments (Fernandes et al. 2009), but a more restricted number of equivalent studies have been conducted on the role of resistant bacteria in food (Simeoni et al. 2008). Reports on the occurrence of b-lactamases among commensal Enterobacteriaceae from RTE food from animal sources are very scarce in Portugal (Amador et al. 2009). The aim of this study was to examine the presence of b-lactam-resistant bacteria in different types of Portuguese RTE meat products (deli meats) as well as to investigate the antimicrobial resistance patterns and the presence of the most abundant ESBLs (TEM, CTX, SHV) and OXYgenes within these bacteria.

\section{MATERIALS AND METHODS}

\section{Characterization of the Deli Meat Products and Sampling}

Nineteen samples, corresponding to 11 types of Portuguese RTE meat (deli meats) products collected in 2007 in the central region of Portugal (Coimbra) were analyzed in this study. With the exceptions of one ham sample, and one meat salad sample, the products were not prepackaged. The deli meats were purchased at two supermarkets, two butchers and one market, and corresponded to pork, turkey or duck meat, and were differently processed (smoked and/or salted and boiled) (Table 1). 
TABLE 1.

CHARACTERIZATION OF PORTUGUESE DELI MEATS WITH RESPECT TO PRODUCT TYPE, ANIMAL ORIGIN, PROCESSING TYPE, PURCHASE SITE AND MEAN VALUES OF AMPICILLIN RESISTANT (AMPR) BACTERIA (cfu/g) ON VRBG PLATES, AFTER 38 h AT $37 \mathrm{C}$

\begin{tabular}{|c|c|c|c|c|c|c|}
\hline Product type code & Product type & Animal origin & Processing & Purchase site & N. of samples & $\mathrm{CFU} / \mathrm{g}$ \\
\hline \multirow[t]{4}{*}{ A } & \multirow[t]{4}{*}{ Ham } & Pork * & \multirow[t]{4}{*}{ Boiled } & Supermarket 1 & \multirow[t]{4}{*}{4} & ND \\
\hline & & Turkey & & Supermarket 1 & & $2.33 \mathrm{E}+05$ \\
\hline & & Pork & & Butcher 1 & & ND \\
\hline & & Pork & & Butcher 2 & & $1.00 \mathrm{E}+05$ \\
\hline \multirow[t]{2}{*}{ B } & \multirow[t]{2}{*}{ Smoked sausage $^{1}$} & \multirow[t]{2}{*}{ Pork } & \multirow[t]{2}{*}{ Smoked } & Butcher 1 & \multirow[t]{2}{*}{3} & $<10^{3}$ \\
\hline & & & & Butcher 2 & & $<10^{3}$ \\
\hline $\mathrm{C}$ & Salted ribs ${ }^{2}$ & Pork & Boiled & Butcher 1 & 1 & $1.10 \mathrm{E}+08$ \\
\hline $\mathrm{D}$ & Cold cuts ${ }^{3}$ & Pork & Smoked and salted & Supermarket 2 & 1 & $1.00 \mathrm{E}+04$ \\
\hline \multirow[t]{3}{*}{$\mathrm{E}$} & \multirow[t]{3}{*}{ Smoked and salted ham ${ }^{4}$} & \multirow[t]{3}{*}{ Pork } & \multirow[t]{3}{*}{ Smoked and salted } & Supermarket 2 & 3 & $<10^{3}$ \\
\hline & & & & Market & & ND \\
\hline & & & & Market & & ND \\
\hline $\mathrm{F}$ & Thick sausage $^{5}$ & Pork & Smoked and salted & Market & 1 & $* *$ \\
\hline \multirow[t]{2}{*}{ G } & Industrial meat salad ${ }^{6}$ & Pork* & \multirow[t]{2}{*}{ Boiled } & Supermarket 2 & 2 & $<10^{3}$ \\
\hline & Artisanal meat salad ${ }^{7}$ & Pork & & Supermarket 2 & & ND \\
\hline I & Smoked and salted loin ${ }^{8}$ & Pork & Smoked and salted & Market & 1 & $* *$ \\
\hline $\mathrm{J}$ & Black smoked sausage $^{9}$ & Pork & Smoked and salted & Supermarket 2 & 1 & $* *$ \\
\hline $\mathrm{L}$ & Large Italian type sausage ${ }^{10}$ & Turkey & Boiled & Butcher 2 & 1 & $6.67 \mathrm{E}+03$ \\
\hline
\end{tabular}

* Prepackaged.

** Negative in $25 \mathrm{~g}$.

(1) Chouriço de carne; (2) costela salgada; (3) assorted parings from paio, salsichão and ham; (4) presunto; (5) paio; (6) meat salad with mayonese; (7) salada de orelha; (8) lombo de porco preto; (9) moiras; (10) mortadela.

(ND) not determined; cfu, colony-forming unit. 
An aliquot of $25 \mathrm{~g}$ was removed from each sample and blended for $2 \mathrm{~min}$, in a Stomacher ${ }^{\circledR}$ (Barcelona, Spain), with $225 \mathrm{~mL}$ of buffered peptone water (BPW) (pH 7.0) supplemented with $50 \mathrm{mg} / \mathrm{mL}$ cycloheximidine (Sigma, St. Louis, MO).

\section{Enumeration of Ampicillin Resistant Bacteria}

The enumeration of ampicillin resistant $\left(\mathrm{AMP}^{\mathrm{r}}\right)$ bacteria was performed on randomly selected colonies on VRBG agar (Violet Red Bile Glucose) agar (Oxoid, Hampshire, England) as follows: portions of $0.1 \mathrm{~mL}$ of the homogenized or of the appropriately diluted meat product samples in BPW containing $50 \mathrm{mg} / \mathrm{mL}$ cycloheximidine, obtained as described above, were immediately surface plated onto three replicate plates of VRBG supplemented with $20 \mathrm{mg} / \mathrm{mL}$ of sodium ampicillin (AppliChem, Damstadt, Germany). Plates were incubated aerobically at $37 \mathrm{C}$ for $38 \mathrm{~h}$ before counting the colonies. VRBG is a selective medium for Enterobacteriaceae when the sample is double-layered and only the purple $(>2 \mathrm{~mm})$ colonies are enumerated after $18 \mathrm{~h}$ at $37 \mathrm{C}$. Once the incubation was performed aerobically for $38 \mathrm{~h}$, all the $\mathrm{AMP}^{\mathrm{r}}$ isolates were counted.

\section{Detection of Ampicillin-Resistant Bacteria}

In order to recover all the resistance phenotypes present in the meat products, each homogenized sample was incubated overnight at 37C, before surface plating on VRBG and on SS (Salmonella \& Shigella) agar (Oxoid). Both media were supplemented with $20 \mathrm{mg} / \mathrm{mL}$ of sodium ampicillin. Plates were incubated aerobically at $37 \mathrm{C}$ for 24 to $48 \mathrm{~h}$. Different morphological types of $\mathrm{AMP}^{\mathrm{r}}$ colonies were selected and the cultures were purified and phenotypically confirmed by re-streaking isolated colonies five times onto the respective isolation medium. Strains Escherichia coli XL1-Blue and Escherichia coli XL1-Blue transformed with plasmid pUC18 (which contains the TEM-1 b-lactamase gene) were used as negative and positive controls, respectively, for $\mathrm{AMP}^{\mathrm{r}}$ phenotypeidentification.

\section{Nitrocefin Test and Antimicrobial Susceptibility Tests}

The detection of b-lactamases produced by the AMPr isolates was performed by adding nitrocefin (Oxoid, Hants, England) to the cell biomass, according to the manufacturer instructions. For the positive nitrocefin strains, the susceptibility pattern determination was performed by the disk diffusion method on Mueller Hinton agar (Oxoid) with antibiotic disks (Oxoid) according to the Clinical Laboratory Standards Institute (CLSI) (Jorgensen and NCCLS 2003; NCCLS 2005). Thirteen different antibiotics were used: amoxicillin/ 
clavulanic acid combination (Clavamox) (AMC) $30 \mathrm{mg} / 10 \mathrm{mg}$, respectively; ceftazidime (CAZ) $30 \mathrm{mg}$; cefotaxime (CTX) $30 \mathrm{mg}$; cefpirome (CPO) $30 \mathrm{mg}$; aztreonam (ATM) $30 \mathrm{mg}$; cefoxitin (FOX) $30 \mathrm{mg}$; imipenem (IPM) $10 \mathrm{mg}$; meropenem (MEM) $10 \mathrm{mg}$; chloramphenicol (CHL) $30 \mathrm{mg}$; tetracycline (TET) $30 \mathrm{mg}$; gentamicin (GEN) $10 \mathrm{mg}$; trimethoprim/sulfamethoxazol (Bactrim®; SXT) combination (1:19) and ciprofloxacin (CIP) $5 \mathrm{mg}$.

In order to observe the influence of clavulanic acid on both CAZ and CTX, these antibiotics were positioned in line, with AMC in the middle. The results of the antimicrobial susceptibilities were interpreted according to the CLSI guidelines.

\section{Bacterial Identification}

The identification of b-lactamase producing isolates randomly selected from VRBG and SS plates was carried out in two steps. First, classical morphological and physiological tests were performed in agreement with the Bergey's Manual of Determinative Bacteriology (Holt 1994). These tests included Gram staining reaction, morphology, motility and biochemical tests: fermentative/oxidative metabolism of glucose (Hugh and Leifson 1953) (fermentation of glucose to acid or to acid and gas), aerobic/anaerobic growth, catalase and oxidase reactions. Subsequently, the isolates identified as belonging to the Enterobacteriaceae family were submitted to additional identification by using standard biochemical methods of API 20E (bioMérieux SA, Marcy l'Etoile, France), following the manufacturer instructions.

\section{Detection of b-Lactamase Genes}

For the detection of four b-lactamase (bla) genes (bla $a_{\mathrm{TEM}}, b l_{\mathrm{SHV}}$ and bla $a_{\text {стХ-м/bla }}$ оху involved in b-lactam resistance a multiplex-PCR approach described by Monstein et al. (2007) was used. Genomic DNA extraction was performed with the guanidine thiocyanate method according to Pitcher et al. (1989) and plasmid DNA extraction was performed with the Kit JETquick Miniprep DNA Genomed (Löhne, Germany). The primers used were synthesized by Metabion International AG (Martinsried, Germany).

Strains E. coli UB0402407 and K. pneumoniae HY0301692 (kindly provided by the Clinical Microbiology Department, Linköping University, Sweden) were used as positive controls for $b l a_{\mathrm{TEM}}+b_{l} a_{\text {СТХ-м }} / b l a_{\mathrm{OXY}}$ genes and bla $_{\mathrm{SHV}}$ gene, respectively. The expected sizes of these amplicons were $445 \mathrm{bp}$

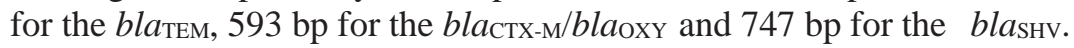

\section{Direct Sequencing of the bla}

In order to discriminate between bla $a_{\text {СтX-м }}$ and bla $a_{\text {OXY }}$ genes direct sequencing of the expected size amplicons was performed. Amplified DNA 
fragments were purified from the agarose gels using the AxyPrep DNA Gel Extraction kit (Axygen Biosciences, Bioron, Germany), according to the manufacturer recommendations and eluted in $30-50 \mathrm{~mL}$ sterile distilled water. Concentration of purified DNA was determined and set to about $1 \mathrm{mg} / \mathrm{mL}$.

The nucleotide sequences were obtained using the DNA sequencing kit, BigDye Terminator Cycle Sequencing Ready Reaction (Applied Biosystems, Foster City, CA) with the primers referred above (Monstein et al. 2007). Briefly, 50 ng of DNA was mixed with 10 pmol of forward or reverse primer, $8 \mathrm{ml}$ of a terminator ready reaction mix and sterile distilled water to a final reaction volume of $20 \mathrm{~mL}$. Amplification conditions were 25 cycles of $96 \mathrm{C}$ for $10 \mathrm{~s}, 50 \mathrm{C}$ for $10 \mathrm{~s}$ and $60 \mathrm{C}$ for $4 \mathrm{~min}$. Rapid removal of unincorporated fluorescent dye-terminators from cycle sequencing reactions was carried out prior to sequencing on Performa DTR Ultra 96-Well Plate (EdgeBio, PN 4050207). Sequence data was obtained on an ABI 3730xl Genetic Analyzer (Applied Biosystems).

DNA from each isolate was used to produce the overlapping PCR products, being the respective sequences assembled to generate the final isolate sequence consensus. All the nucleotide sequences in this study were obtained from one unique isolate.

\section{RESULTS AND DISCUSSION}

\section{Enumeration of Ampicillin Resistant Bacteria and Detection of b-Lactamases}

The enumeration of AMP ${ }^{r}$ bacteria recovered from the deli meat products was performed on nine samples randomly selected, belonging to seven types of meat products (A, B, C, D, E, G and L) (Table 1). The counting data of $\mathrm{AMP}^{\mathrm{r}}$ bacteria on VRBG plates varied from negative in $25 \mathrm{~g}$ to $1.0 ¥ 10^{8}$ colony-forming units (cfu)/g (Table 1). In general, the numbers of $\mathrm{AMP}^{\mathrm{r}}$ isolates were lower in smoked products (types B and E). The industrial meat salad (type G), besides being prepacked, had in its formulation different preservatives that could account for the low numbers that can be deduced from the test $\left(<10^{3} \mathrm{cfu} / \mathrm{g}\right)$.

Antibiotic-resistant microorganisms were also reported at levels ranging from $10^{2}$ to $10^{7} \mathrm{CFU} / \mathrm{g}$, in the majority of retail foods examined, in the United States, including raw foods, such as meat and shrimp, and RTE products, such as cheeses and salads (Wang et al. 2005).

In order to recover all the resistance phenotypes present in deli meats, even stressed ones because of the processing type, a total of $78 \mathrm{AMP}^{\mathrm{r}}$ isolates were recovered, after the enrichment step, from VRBG and from SS plates. 
These isolates were screened for the presence of $b$-lactamases by the nitrocefin test. All the AMPr isolates were found to be positive for the presence of blactamases. Both media used to recover b-lactam-resistant bacteria appeared to be suitable for this objective, as only one (1.3\% of the isolates) and seven (9\% of the isolates) from a total of $78 \mathrm{~b}$-lactamase producers subjected to identification were recovered exclusively either from SS or from VRBG plates, respectively (Table 2 ). No isolates were recovered, after enrichment, from product type F, I and $\mathrm{J}$ (thick sausage, smoked and salted loin and black smoked sausage, respectively) (Tables 1 and 2).

\section{Bacterial Identification}

Of the 78 nitrocefin positive isolates (46 from VRBG and 32 from SS plates), $87.2 \%$ were identified as belonging to the Enterobacteriaceae family, $9.0 \%$ to the Pseudomonas genus and $3.8 \%$ to the Aeromonas genus (Table 2). Within the Enterobacteriaceae family, 42 isolates (16 from SS and 26 from VRBG plates) were identified as belonging to 11 different species. It was not possible to identify 26 of the Enterobacteriaceae isolates (33.3\%) recovered from both media to the species level. The type of meat product D (cold cuts) was the source of the highest number of identified Enterobacteriaceae (26 isolates corresponding to five different species). This might be ascribed to the fact that it was composed of parings of three types of deli meat. After the enrichment step, six different species were collected from the artisanal meat salad (product type G), namely, Morganella morganii, Enterobacter cloacae, $K$. oxytoca, K. pneumoniae spp. pneumoniae, Pseudomonas aeruginosa and $P$. fluorescens (Table 2).

The criteria listed for Enterobacteriaceae in the PHLS document (Gilbert et al. 2000) regarding the microbiological quality of RTE foods sampled at the point of sale do not apply to fresh fruit and vegetables or to sandwiches containing salad vegetables because fresh fruit and vegetables often carry high levels of these organisms as part of their normal flora. For the other categories of RTE foods (including the type of deli meats analyzed here) food products presenting Enterobacteriaceae counts that exceed $10^{4} \mathrm{cfu} / \mathrm{g}$ are considered unsatisfactory (Gilbert et al. 2000). As 87.2\% of the identified isolates resided within the Enterobacteriaceae family, the samples submitted for enumeration corresponding to product types $\mathrm{A}, \mathrm{C}$ and $\mathrm{D}$, according to these guidelines would probably have been considered unsatisfactory (Table 1). As Enterobacteriaceae are used as a parameter in process hygiene criteria, the results presented here suggest a lack of hygiene at one or more of the processing stages of these products and/or growth during distribution and storage at retail outlets. In order to avoid deli meat contamination with these and other potential hazardous bacteria, the existence of good sanitary conditions during 
TABLE 2.

IDENTIFICATION OF AMPICILLIN RESISTANT ISOLATES POSITIVE FOR THE NITROCEFIN TEST, AND RESPECTIVE TYPE OF DELI MEAT AND RECOVERY MEDIUM

\begin{tabular}{|c|c|c|c|c|c|}
\hline Family/genus & Species & N. of isolates & $\%$ & Type of meat product & Recovery medium \\
\hline \multirow[t]{12}{*}{ Enterobacteriaceae } & NI & 26 & 33.3 & $\mathrm{~A}, \mathrm{D}, \mathrm{E}, \mathrm{H}, \mathrm{L}$ & VRBG, SS \\
\hline & Cedecea davisae & 2 & 2.6 & $\mathrm{H}$ & VRBG \\
\hline & Escherichia coli & 12 & 15.4 & $\mathrm{~B}, \mathrm{C}, \mathrm{D}$ & VRBG, SS \\
\hline & Morganella morganii & 2 & 2.6 & $\mathrm{D}, \mathrm{G}$ & VRBG, SS \\
\hline & Enterobacter cloacae & 4 & 5.1 & $\mathrm{~A}, \mathrm{C}, \mathrm{G}$ & VRBG, SS \\
\hline & Escherichia vulneris & 4 & 5.1 & $\mathrm{~B}, \mathrm{C}$ & VRBG, SS \\
\hline & Klebsiella oxytoca & 6 & 7.7 & A, D, E, G & VRBG, SS \\
\hline & K. pneumoniae ssp. ozaenae & 1 & 1.3 & $\mathrm{~B}$ & VRBG \\
\hline & Enterobacter amnigenus & 3 & 3.8 & $\mathrm{~A}, \mathrm{E}$ & VRBG \\
\hline & Enterobacter aerogenes & 1 & 1.3 & $\mathrm{~A}$ & VRBG \\
\hline & $\begin{array}{l}\text { K. pneumoniae ssp. } \\
\text { pneumoniae }\end{array}$ & 6 & 7.7 & $\mathrm{~B}, \mathrm{D}, \mathrm{E}, \mathrm{G}$ & VRBG, SS \\
\hline & Serratia liquefaciens & 1 & 1.3 & $\mathrm{H}$ & SS \\
\hline \multirow[t]{3}{*}{ Pseudomonas } & NI & 2 & 2.6 & $\mathrm{~B}, \mathrm{G}$ & VRBG, SS \\
\hline & Pseudomonas aeruginosa & 2 & 2.6 & $\mathrm{G}$ & VRBG, SS \\
\hline & Pseudomonas fluorescens & 3 & 3.8 & $\mathrm{~B}, \mathrm{G}$ & VRBG, SS \\
\hline Aeromonas & $\mathrm{NI}$ & 3 & 3.8 & A & VRBG, SS \\
\hline All & & 78 & 100 & $\mathrm{~A}, \mathrm{~B}, \mathrm{C}, \mathrm{D}, \mathrm{E}, \mathrm{G}, \mathrm{H}, \mathrm{L}$ & VRBG, SS \\
\hline
\end{tabular}

VRBG, Violet Red Bile Glucose agar; SS, Salmonella/Shigella agar; NI, not identified; A, ham; B, smoked sausage; C, salted ribs; D, cold cuts; E, smoked and salted ham; F, thick sausage; G, meat salad; H, pâté; I, smoked and salted loin; J, black smoked sausage; L, large Italian type sausage. 


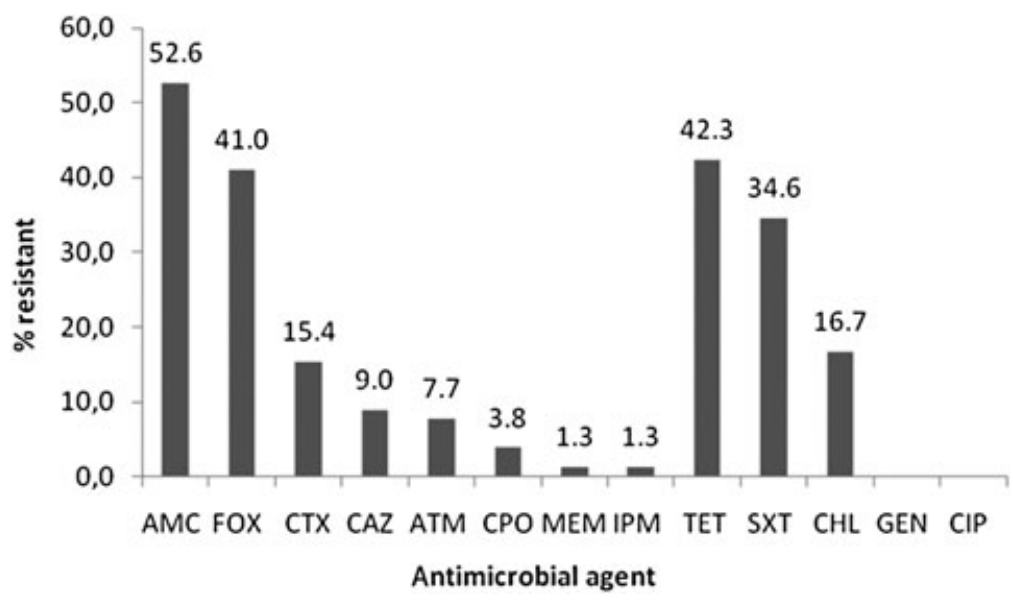

FIG. 1. PERCENTAGE OF THE RESISTANT PHENOTYPE FOR THE ANTIMICROBIAL AGENTS TESTED AMONG THE ISOLATED AMPICILLIN RESISTANT/NITROCEFIN POSITIVE DELI MEAT ISOLATES

The antimicrobial agents tested were the b-lactams: AMC, amoxicillin/clavulanic acid (30:10 mg); FOX, cefoxitin $(30 \mathrm{mg})$; CTX, cefotaxime $(30 \mathrm{mg})$; CAZ, ceftazidime $(30 \mathrm{mg})$; ATM, aztreonam (30 mg); CPO, cefpirome (30 mg); MEM, meropenem (10 mg); IPM, imipenem (10 mg); and the non-b-lactams: TET, tetracycline (30 mg); SXT, trimethoprim/sulfamethoxazole (1:19 mg); CHL, choranfenicol (30 mg); GEN, gentamicin (10 mg); and CIP, ciprofloxacin (5 mg).

animal slaughtering and meat processing are obligatory. This includes herd health management and hygiene along the entire production chain.

\section{Antimicrobial Susceptibility Tests}

The determination of antimicrobial susceptibility and resistance for the 13 antimicrobial agents revealed a higher resistance in the b-lactams group AMC (52.6\%) and FOX (41.0\%) and in the non-b-lactam group TET (42.3\%), followed by SXT (34.6\%) (Fig. 1). Conversely, the most effective antimicrobials were GEN and CIP (100\% each) and IPM and MEM (98.7\% each) (Fig. 1).

The antimicrobial susceptibility of the meat isolates to these 13 antimicrobial agents was compared with bacterial isolates from cheese in a previous study (Amador et al. 2009). The antimicrobial susceptibility data obtained in the present study were similar to those described for isolates recovered from cheese samples that showed values of antimicrobial resistance to AMC, FOX, TET and SXT of 51.7, 46.5, 46.5 and 38.4\%, respectively. Similarly, the most efficient antimicrobials were GEN (98.3\%), CIP (97.7\%), IPM (95.3\%) and MEM (90.7\%). 
A possible explanation for the high incidence of resistance observed in meat products predominantly made of pork might be the intensive use in pig farming of antibiotics including streptomycin, penicillin, amoxicillin/ clavulanic acid, oxytetracycline, tylosin, colistin, trimethoprim/sulfamethoxazol, tiamotin, among others (Silbergeld et al. 2008). In fact, meat isolates are possibly a result of enterobacterial contamination during slaughtering and have therefore been submitted to selective pressure of the antimicrobial agents used.

The high frequency of resistance to b-lactams, such as penicillins and their inhibitors, cefalosporins and cefoxitin may be explained by the extensive use in Portugal. Latest data from The National (Portuguese) Authority of Medicines and Health Products (INFARMED, I.P.), kindly provided by this organization, indicate that b-lactams were still the most sold group in this country, reaching a total of $49.2 \%$ (data not shown) of all antibiotic units (packages) according to the report of 2008.

The high resistance detected to TET (42.3\%), similar to levels previously obtained in cheese isolates (46.5\%) (Amador et al. 2009), may be related to the extensive use of TET in veterinary practice (Emborg et al. 2007; Stine et al. 2007; Nawaz et al. 2008). Nevertheless, it could also mean an eventual nonefficiency in humans through selection, following the widespread use of these antibiotics (Nawaz et al. 2008). These results are also in agreement with the work of Simeoni et al. (2008), where from an entire swine production chain, $72 \%$ of the Staphylococcus isolates had two types of resistance determinants to tetracycline, namely tet $(\mathrm{K})$ and tet $(\mathrm{M})$ genes, showing a wide spread of this type of resistance.

Curiously, the high bacterial susceptibility to CIP, already reported by Amador et al. (2009) in Portugal, is in contrast with reports from other European countries, where this type of antibiotics is one of the most frequently used (Ferech et al. 2006).

A multidrug-resistant (MDR) phenotype was defined for isolates resistant to three or more antimicrobial agents that were structurally unrelated. This analysis revealed that $35.9 \%$ of the different phenotypes detected displayed a MDR phenotype (Table 3). The most prevalent resistance phenotypes were AMP (21.8\%), AMP + SXT + TET (11.5\%), AMP + AMC (10.3\%) followed by the AMP + TET and AMP + AMC + FOX (each 7.7\%).

In a previous study by Amador et al. (2009) regarding resistant isolates from cheese, the relative frequency of a particular resistance phenotype was similar to the values found in this study with isolates with the same resistance profile.

Relative frequency of MDR phenotypes detected among deli meat isolates found in the present study was quite elevated (35.9\%) and similar to the value observed among cheese isolates (31.4\%) (Amador et al. 2009). These 
TABLE 3.

RELATIVE FREQUENCY OF RESISTANCE PHENOTYPES AND GENOTYPES DETECTED AMONG DELI MEAT ISOLATES

\begin{tabular}{|c|c|c|c|c|c|c|c|}
\hline & \multirow[t]{3}{*}{ Resistance phenotype } & \multirow{2}{*}{\multicolumn{2}{|c|}{ Phenotype }} & \multicolumn{4}{|l|}{ Genotype } \\
\hline & & & & \multicolumn{2}{|l|}{ TEM } & \multicolumn{2}{|l|}{ CTX-M/OXY } \\
\hline & & $\begin{array}{l}\mathrm{N}^{\circ} \\
\text { isolates }\end{array}$ & $\mathrm{RF}$ & (a) & (b) & (a) & (b) \\
\hline \multirow{13}{*}{ 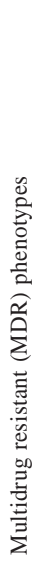 } & AMP, SXT, TET & 9 & 11.5 & $100.0(9 / 9)$ & 39.1 & $0.0(0 / 9)$ & 0.0 \\
\hline & AMP, AMC, FOX, CHL, TET & 4 & 5.1 & $50.0(2 / 4)$ & 8.7 & $0.0(0 / 4)$ & 0.0 \\
\hline & AMP, AMC, FOX, CHL, SXT & 2 & 2.6 & $0.0(0 / 2)$ & 0.0 & $0.0(0 / 2)$ & 0.0 \\
\hline & $\begin{array}{l}\text { AMP, AMC, FOX, CEPH3, } \\
\text { CHL, SXT, TET }\end{array}$ & 2 & 2.6 & $0.0(0 / 2)$ & 0.0 & $0.0(0 / 2)$ & 0.0 \\
\hline & AMP, AMC, FOX, SXT, TET & 2 & 2.6 & $50.0(1 / 2)$ & 4.3 & $0.0(0 / 2)$ & 0.0 \\
\hline & AMP, CHL, SXT, TET & 2 & 2.6 & $100.0(2 / 2)$ & 8.7 & $0.0(0 / 2)$ & 0.0 \\
\hline & $\begin{array}{l}\text { AMP, AMC, CEPH3, CPO, } \\
\text { CHL, SXT, TET }\end{array}$ & 1 & 1.3 & $0.0(0 / 1)$ & 0.0 & $0.0(0 / 1)$ & 0.0 \\
\hline & $\begin{array}{l}\text { AMP, AMC, CEPH3, CPO, } \\
\text { CHL, TET }\end{array}$ & 1 & 1.3 & $100.0(1 / 1)$ & 4.3 & $0.0(0 / 1)$ & 0.0 \\
\hline & $\begin{array}{l}\text { AMP, AMC, FOX, CEPH3, } \\
\text { CPO, ATM, SXT }\end{array}$ & 1 & 1.3 & $0.0(0 / 1)$ & 0.0 & $0.0(0 / 1)$ & 0.0 \\
\hline & $\begin{array}{l}\text { AMP, AMC, FOX, CEPH3, SXT, } \\
\text { TET }\end{array}$ & 1 & 1.3 & $0.0(0 / 0)$ & 0.0 & $0.0(0 / 0)$ & 0.0 \\
\hline & AMP, AMC, SXT, TET & 1 & 1.3 & $100.0(1 / 1)$ & 4.3 & $0.0(0 / 1)$ & 0.0 \\
\hline & AMP, FOX, CHL, SXT & 1 & 1.3 & $0.0(0 / 1)$ & 0.0 & $0.0(0 / 1)$ & 0.0 \\
\hline & AMP, FOX, SXT, TET & 1 & 1.3 & $0.0(0 / 1)$ & 0.0 & $0.0(0 / 1)$ & 0.0 \\
\hline \multicolumn{2}{|c|}{ Sub-total } & 28 & 35.9 & $59.3(16 / 27)$ & 69.6 & $0.0(0 / 27)$ & 0.0 \\
\hline \multirow{11}{*}{ 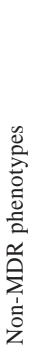 } & AMP & 17 & 21.8 & $15.4(2 / 13)$ & 8.7 & $30.8(4 / 13)$ & 100.0 \\
\hline & AMP, AMC & 8 & 10.3 & $0.0(0 / 7)$ & 0.0 & $0.0(0 / 7)$ & 0.0 \\
\hline & AMP, TET & 6 & 7.7 & $0.8(4 / 5)$ & 17.4 & $0.0(0 / 5)$ & 0.0 \\
\hline & AMP, AMC, FOX & 6 & 7.7 & $0.0(0 / 5)$ & 0.0 & $0.0(0 / 5)$ & 0.0 \\
\hline & AMP, AMC, FOX, CEPH3, ATM & 5 & 6.4 & $20.0(1 / 5)$ & 4.3 & $0.0(0 / 5)$ & 0.0 \\
\hline & AMP, AMC, FOX, SXT & 2 & 2.6 & $0.0(0 / 1)$ & 0.0 & $0.0(0 / 1)$ & 0.0 \\
\hline & AMP, FOX, TET & 2 & 2.6 & $0.0(0 / 1)$ & 0.0 & $0.0(0 / 1)$ & 0.0 \\
\hline & AMP, AMC, FOX, CEPH3 & 1 & 1.3 & $0.0(0 / 1)$ & 0.0 & $0.0(0 / 1)$ & 0.0 \\
\hline & AMP, AMC, FOX, CEPH3, SXT & 1 & 1.3 & $0.0(0 / 1)$ & 0.0 & $0.0(0 / 1)$ & 0.0 \\
\hline & AMP, AMC, FOX, TET & 1 & 1.3 & $0.0(0 / 0)$ & 0.0 & $0.0(0 / 0)$ & 0.0 \\
\hline & AMP, AMC, SXT & 1 & 1.3 & $0.0(0 / 1)$ & 0.0 & $0.0(0 / 1)$ & 0.0 \\
\hline \multicolumn{2}{|c|}{ Subtotal } & 50 & 64.1 & $17.5(7 / 40)$ & 30.4 & $10.0(4 / 40)$ & 100.0 \\
\hline \multicolumn{2}{|c|}{ Total } & 78 & 100 & $34.3(23 / 67 *)$ & 100.0 & $6.0\left(4 / 67^{*}\right)$ & 100.0 \\
\hline
\end{tabular}

* Eleven out of 78 isolates irreversibly lost viability. For this only 67 isolates were tested for the presence of the b-lactamases genes.

(a) Relative frequency of blaTEM or blaCTX-M/OXY positive results in $\mathrm{mPCR} /$ number of tested isolates; in brackets, number of bla TEM or blaCTX-M/OXY positive results in $\mathrm{mPCR} /$ number of tested isolates. (b) Relative frequency of blaTEM or blaCTX-M/OXY positive results in $\mathrm{mPCR} /$ total number of positive results in $\mathrm{mPCR}$ tests.

Antimicrobials: AMC, amoxicillin/clavulanic acid; AMP, ampicillin; ATM, aztreonam; CHL, choranfenicol; CPO, cefpirome; FOX, cefoxitin; SXT, trimethoprim/sulfamethoxazole; TET, tetracycline; CEPH3, third cephalosporins (cefotaxime and/or ceftazidime); RF, relative frequency of meat isolate's resistance phenotype. 
elevated MDR phenotypes are also in agreement with the results of Fernandes et al. (2008) that reported the spreading of MDR in Portuguese hospitals and in the community by isolates encoding for ESBLs. Increased prevalence of MDR phenotypes were also found all over Europe (Livermore et al. 2007).

\section{Detection of b-Lactamase Genes}

Seventy eight randomly selected ampicillin resistant isolates were investigated for resistance phenotype pattern and genus/species identification. Nevertheless, 11 isolates irreversibly lost viability. The remaining 67 isolates were then tested for the presence of four b-lactamases genes with multiplexPCR (Table 3). This analysis showed that 34.3\% (23/67) of the isolates harbored a gene coding for the TEM-type enzyme (bla $\left.a_{\mathrm{TEM}}\right)$ and $6.0 \%(4 / 67)$ of the isolates harbor a gene for the CTX-M/OXY-type enzymes (bla $b a_{\mathrm{OXY}}$, respectively). No bla $a_{\mathrm{CTX}-\mathrm{M}}$ and $b a_{\mathrm{SHV}}$ were detected among the isolates under study (Table 3).

The bla isolates with MDR phenotypes, than among those with non-MDR phenotypes $(17.5 \%, 7 / 40)$, although a higher number of isolates of the latter group were tested. The bla $\mathrm{AMP}+\mathrm{SXT}+\mathrm{TET}$ resistance profile.

The high number of isolates with bla $a_{\text {TEM }}$ genes might be explained by the wide dissemination of plasmids coding for TEM enzymes, sometimes in mobile genetic elements, which are responsible for the broad-spectrum resistance phenotype to penicillin in many gram-negative bacteria, namely E. coli, in clinical isolates (Schmitt et al. 2007). Recently, an alarming level of TEM frequency was reported in Chinese chicken farms (Yuan et al. 2009).

The presence of bla TEM in bacteria isolated from deli meats reported in this study, is in agreement with several recent reports showing that TEM b-lactamases are particularly involved in resistance phenotypes presented by bacteria isolated from several agro-industrial environments such as livestock (Kim et al. 2005; Cloeckaert et al. 2007; Sunde et al. 2009). The presence of TEM b-lactamases in these bacteria may be explained by its insertion between transposable elements that move rapidly through bacterial populations (Partridge and Hall 2005) and may become a major public health concern. Several studies have reported this transfer of antimicrobial resistance genes from food bacteria to human flora in the food chain (Angulo et al. 2004; Phillips et al. 2004; Simeoni et al. 2008).

The pair of primers used to amplify bla $a_{\mathrm{CTX}}$ was proved to also target the bla $a_{\text {OXY }}$ gene, therefore detecting both without discrimination, for which sequencing is required (Monstein et al. 2007; Monstein et al. 2009). A BLAST search for similarity with the sequences produced revealed no similarity between $b a_{\text {CTX-м }}$ and bla ${ }_{\text {OXY }}$ (data not shown). 
In the present study, bla oxy genes were exclusively detected in the AMP resistance profiles of four isolates of $K$. oxytoca designated as $3 \mathrm{C}$ (from cold cuts), 35C (from meat salad), 36C (from smoked and salted ham) and 76C (from meat salad). This organism is usually reported as a clinical isolate.

These results are not consistent with the phenotypes of resistance that have been found in isolates of $K$. oxytoca resistant to broad-spectrum cephalosporins and to monobactam (except ceftazidime, cephamycins and carbapenems), which represent overproduction of b-lactamases chromosomally encoded, because of some mutations in the promoter regions -35 and -10 (Mammeri et al. 2003; Schmitt et al. 2007).

The sequences of the amplicons from the four $K$. oxytoca isolates were deposited in the EMBL/GenBank/ DDBJ database with the accession numbers: GQ433982 (isolate 3C), GQ433983 (isolate 35C), GQ433980 (isolate 36C) and GQ433981 (isolate 76C).

These sequences were then compared with others, from clinical reference strains of $K$. oxytoca recovered at hospitals in Canada, Denmark, France, Sweeden, Switzerland and the Netherlands (Fournier et al. 1995; Wu et al. 1999; Granier et al. 2003; Fevre et al. 2005). The sequences from these clinical isolates are representative of the six groups of the OXY b-lactamase (Fevre et al. 2005) and were retrieved from EMBL/GenBank/DDBJ database. The nucleotide sequences GQ433980 and GQ433981 were more similar (within 98\% and 99\%) to sequences (Y17714, Z49084, FM178458 and FM178457), whereas the GQ433982 was more similar (97\%) to sequences (AJ871871 and AJ871872) and GQ433983 was more similar (98\%) to sequences (AY077482 and Z30177). Therefore, based on the available data, three blaoxy genes were identified namely the bla $a_{\mathrm{OXY}-2}$ gene in isolates $36 \mathrm{C}$ and $76 \mathrm{C}$, the bla ${ }_{\mathrm{OXY}-5}$ gene in isolate $3 \mathrm{C}$ and the bla $\mathrm{OXY}_{\mathrm{X}-1}$ gene in isolate $35 \mathrm{C}$.

The alignment of the deduced bla $\mathrm{Oxy}$ aminoacidic sequences with the others referred to above (Fig. 2) showed that aminoacidic sequences deduced from the sequences of isolates $36 \mathrm{C}$ and $76 \mathrm{C}$ were similar to sequences $\mathrm{Y} 17714$ (98 and 99\%), Z49084 (98 and 99\%), FM178458 (98 and 98\%) and FM178457 (99 and 98\%), respectively.

The deduced sequence from isolate $3 \mathrm{C}$ is $98 \%$ similar to OXY-5 sequences AJ871871 and AJ871872, of strains SB2933 and SB2942 and the 35C is similar to OXY-1 sequences AY077482 (99\%) and Z30177 (100\%), obtained from strain SG12 and reference strain SL781.

The isolates carrying chromosomal blaOXY, as described in the present study, may only represent a risk to public health if a genetic transfer mechanism from chromosome to plasmid takes place, as occurred with other blactamase genes. Several studies have shown that resistance chromosome genes may be transferred to plasmids by recombination mechanisms. For example, Bonnet (2004) suggested the mobilization of bla $a_{\text {Стх-м }}$ genes from the 

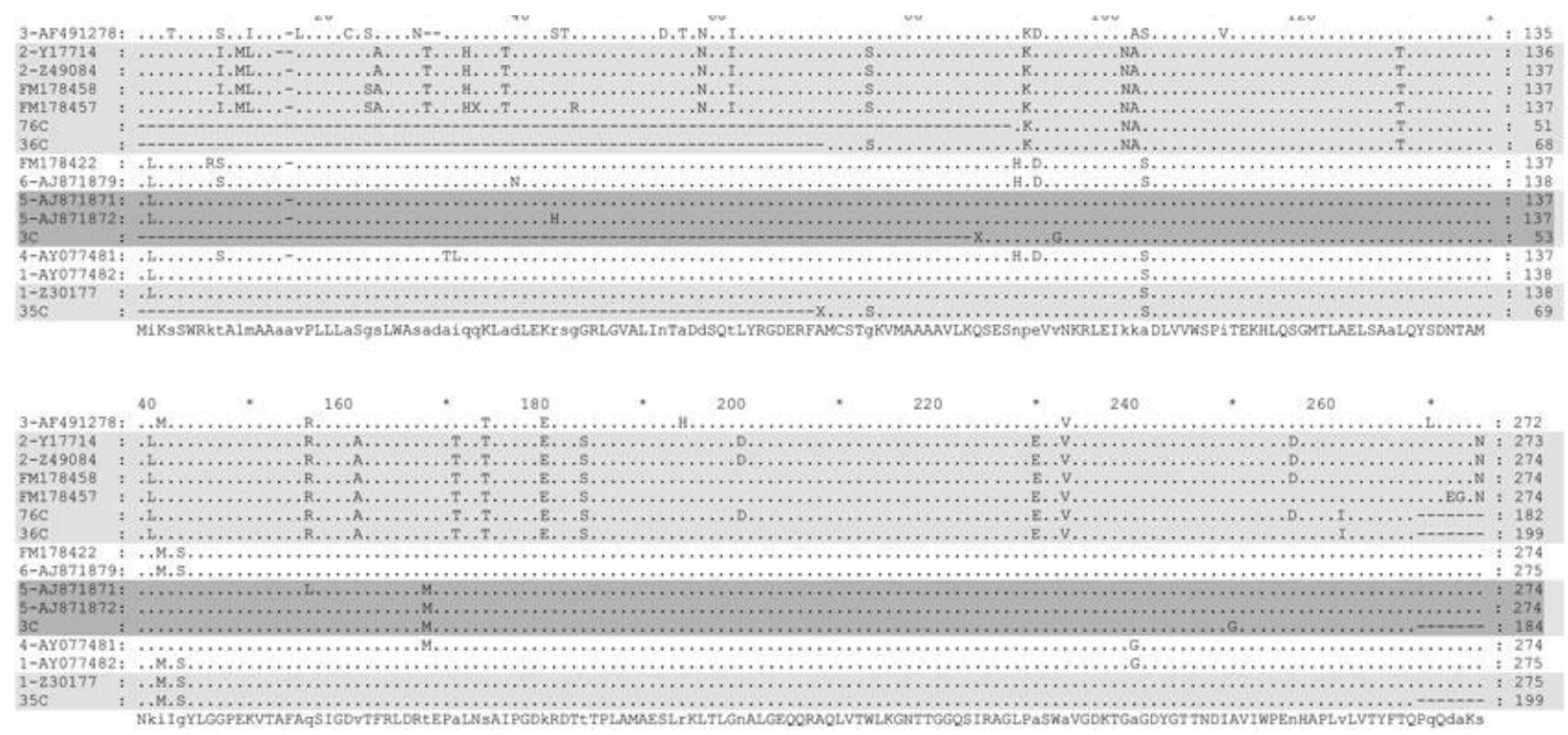

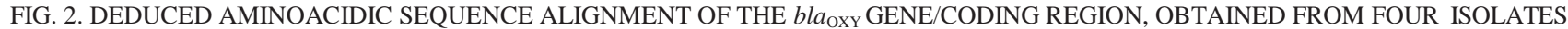
(76C, 36C, 35C, 3C) AND 12 SEQUENCES RETRIEVED FROM EMBL/GENBANK/DDBJ DATABASE (Y17714, Z49084, FM178458, FM178457, FM178422, AJ871879, AJ871872, AJ871871, AY077481, AY077482, Z30177 AND AF491278)

Hyphens represent gaps included in the sequence. 
chromosomes of environmental Kluyvera bacteria to plasmids. That is why conjugation and transformation studies are still performed in order to understand possible transmission mechanisms of these genes (Fournier et al. 1996; Granier et al. 2003; Mammeri et al. 2003; Decré et al. 2004).

To our knowledge, this is the first report in Portugal of the presence of b-lactam resistant bacteria in deli meats, a type of RTE food product. This is also the first Portuguese report describing the presence of $K$. pneumoniae ssp. in food. The data presented here confirm previous statements that food can contribute to the spread of antibiotic resistant Enterobacteriaceae in the community (Prats et al. 2003) namely by transfer of b-lactam-resistant bacteria to the gastro-intestinal (GI) flora of the consumer. This would also accentuate the importance of good hygienic practices during food animal slaughtering and/or processing, distribution and storage.

\section{ACKNOWLEDGMENTS}

The authors thank Dr. Maria Tärnberg for providing the strains $E$. coli UB0402407 and K. pneumonia HY0301692 used as positive controls in multiplex PCR, Dr. Isabel Duarte and Dr. Marques Pinto for assistance in sequence assembling and bacterial identification, respectively.

\section{REFERENCES}

AARESTRUP, F.M. 1999. Association between the consumption of antimicrobial agents in animal husbandry and the occurrence of resistant bacteria among food animals. Int. J. Antimicrob. Agents. 12, 279-285.

AMADOR, P., FERNANDES, R., PRUDÊNCIO, C. and BRITO, L. 2009. Resistance to b-lactams in bacteria isolated from different types of Portuguese cheese. Int. J. Mol. Sci. 10, 1538-1551.

ANGULO, F.J., NARGUND, V.N. and CHILLER, T.C. 2004. Evidence of an association between use of antimicrobial agents in food animals and antimicrobial resistance among bacteria isolated from humans and the human health consequences of such resistance. J Vet Med B. 51, 374379.

ANONYMOUS 2007. Commission Regulation (EC) No 1441/2007, $5^{\text {th }}$ December 2007. Official Journal of the European Community, L322/1229.

BONNET, R. 2004. Growing group of extended-spectrum beta-lactamases: the CTX-M enzymes. Antimicrob. Agents Chemother. 48, 1-14. 
CLOECKAERT, A., PRAUD, K., DOUBLET, B., BERTINI, A., CARATTOLI, A., BUTAYE, P., IMBERECHTS, H., BERTRAND, S., COLLARD, J.M., ARLET, G. ET AL. 2007.Dissemination of an extended-spectrum-beta-lactamase blaTEM-52 gene-carrying IncI1 plasmid in various Salmonella enterica serovars isolated from poultry and humans in Belgium and France between 2001 and 2005. Antimicrob. Agents Chemother. 51, 1872-1875.

DECRÉ, D., BURGHOFFER, B., GAUTIER, V., PETIT, J.-C. and ARLET, G. 2004. Outbreak of multi-resistant Klebsiella oxytoca involving strains with extended-spectrum b-lactamases and strains with extendedspectrum activity of the chromosomal b-lactamase. J. Antimicrob. Chemother. 54, 881-888.

EMBORG, H.D., VIGRE, H., JENSEN, V.F., VIEIRA, A.R.P., BAGGESEN, D.L. and AARESTRUP, F.M. 2007. Tetracycline consumption and occurrence of tetracycline resistance in Salmonella Typhimurium phage types from Danish pigs. Microb. Drug Resist. 13, 289-294.

FERECH, M., COENEN, S., MALHOTRA-KUMAR, S., DVORAKOVA, K., HENDRICKX, E., SUETENS, C., GOOSSENS, H. and ESAC PROJECT GROUP 2006. European Surveillance of Antimicrobial Consumption (ESAC): Outpatient quinolone use in Europe. J. Antimicrob. Chemother. 58, 423-427.

FERNANDES, R., GESTOSO, A., FREITAS, J.M., SANTOS, P. and PRUDÊNCIO, C. 2009. High resistance to fourth-generation cephalosporins among clinical isolates of Enterobacteriaceae producing extended-spectrum beta-lactamases isolated in Portugal. Int. J. Antimicrob. Agents 33, 184-185.

FERNANDES, R., VIEIRA, M., FERRAZ, R. and PRUDÊNCIO, C. 2008. Bloodstream infections caused by multidrug-resistant Enterobacteriaceae: Report from two Portuguese hospitals. J. Hosp. Infect. 70, 9395.

FEVRE, C., JBEL, M., PASSET, V., WEILL, F.X., GRIMONT, P.A.D. and BRISSE, S. 2005. Six groups of OXY b-lactamase evolved over millions of years in Klebsiella oxytoca. Antimicrob. Agents Chemother. 49, 34533462.

FOURNIER, B., LU, C.Y., LAGRANGE, P.H., KRISHNAMOORTHY, R. and PHILIPPON, A. 1995. A. Point mutation in the pribnow box, the molecular basis of beta-lactamase overproduction in Klebsiella oxytoca. Antimicrob. Agents Chemother. 39, 1365-1368.

FOURNIER, B., ROY, P.H., LAGRANGE, P.H. and PHILIPPON, A. 1996. Chromosomal b-lactamase genes of Klebsiella oxytoca are divided into two main groups, bla oxy-1 and bla oxy-2. Antimicrob. Agents Chemother. 40, 454-459. 
GEVERS, D., DANIELSEN, M., HUYS, G. and SWINGS, J. 2003. Molecular characterization of tet(M) genes in Lactobacillus isolates from different types of fermented dry sausage. Appl. Environ. Microbiol. 69, 1270-1275. GILBERT, R.J., LOUVOIS, J., DONOVAN, T., LITTLE, C., NYE, K., RIBEIRO, C.D., RICHARDS, J., ROBERTS, D. and BOLTON, F.J. 2000. Guidelines for the microbiological quality of some ready-to-eat foods sampled at the point of sale. PHLS Advisory Committee for Food and Dairy Products. Commun. Dis. Public Health 3, 163-167.

GNIADKOWSKI, M. 2001. Evolution and epidemiology of extendedspectrum b-lactamases (ESBLs) and ESBL-producing microorganisms. Clin. Microbiol. Infect. 7, 597-608.

GRANIER, S.A., PLAISANCE, L., LEFLON-GUIBOUT, V., LAGIER, E., MORAND, S., GOLDSTEIN, F.W. and NICOLAS-CHANOINE, M.H. 2003. Recognition of two genetic groups in the Klebsiella oxytoca taxon on the basis of chromosomal beta-lactamase and housekeeping gene sequences as well as ERIC-1R PCR typing. Int. J. Syst. Evol. Microbiol. 53, 661-668.

HOLT, J.G. 1994. Bergey's Manual of Determinative Bacteriology, Lippincott Williams and Wilkins, Philadelphia, PA.

HUGH, R. and LEIFSON, E. 1953. The taxonomic significance of fermentative versus oxidative metabolism of carbohydrates by various gram negative bacteria. J. Bacteriol. 66, 24-26.

INSTITUTE OF FOOD TECHNOLOGISTS (IFT) 2006. Antimicrobial resistance: Implications for the food system. Compr. Rev. Food Sci. Food Saf. 5, 71-137.

JORGENSEN, J.H. and NCCLS 2003. Methods for Dilution Antimicrobial Susceptibility Test for Bacteria That Grow Aerobically, 6th Ed., Clinical and Laboratory Standards Institute, Wayne, PA,pp. M7-A6.

KIM, S.H., WEI, C.I. and AN, H. 2005. Molecular characterization of multidrug-resistant Proteus mirabilis isolates from retail meat products. J. Food Prot. 68, 1408-1413.

LIVERMORE, D.M., CANTON, R., GNIADKOWSKI, M., NORDMANN, P., ROSSOLINI, G.M., ARLET, G., AYALA, J., COQUE, T.M., KERNZDANOWICZ, I., LUZZARO, F. ET AL. 2007.CTX-M: changing the face of ESBLs in Europe. J. Antimicrob. Chemother. 59, 165-174.

MACHADO, E., COQUE, T.M., CANTÓN, R., SOUSA, J.C. and PEIXE, L. 2008. Antibiotic resistance integrons and extended-spectrum blactamases among Enterobacteriaceae isolates recovered from chickens and swine in Portugal. J. Antimicrob. Chemother. 62, 296-302.

MACOVEI, L. and ZUREK, L. 2007. Influx of Enterococci and associated antibiotic resistance and virulence genes from ready-to-eat food to the human digestive tract. Applied Environ. Microbiol. 73, 6740-6747. 
MAMMERI, H., POIREL, L. and NORDMANN, P. 2003. In vivo selection of a chromosomally encoded b-lactamase variant conferring ceftazidime resistance in Klebsiella oxytoca. Antimicrob. Agents Chemother. 47, 3739-3742.

MESA, R.J., BLANC, V., BLANCH, A.R., CORTÉS, P., GONZÁLEZ, J.J., LAVILLA, S., MIRÓ, E., MUNIESA, M., SACO, M., TÓRTOLA, M.T. ET AL. 2006.Extended-spectrum b-lactamase-producing Enterobacteriaceae in different environments (humans, food, animal farms and sewage). J. Antimicrob. Chemother. 58, 211-215.

MONSTEIN, H.J., ÖSTHOLM-BALKHED, Å., NILSSON, N.V., NILSSON, M., DORNBUSCH, K. and NILSSON, L.E. 2007. Multiplex PCR amplification assay for the detection of bla $a_{\mathrm{SHV}}$, bla $a_{\mathrm{TEM}}$ and $b l a_{\mathrm{CTX}-\mathrm{M}}$ genes in Enterobacteriaceae. APMIS 115, 1400-1408.

MONSTEIN, H.J., TÄRNBERG, M. and NILSSON, L.E. 2009. Molecular identification of CTX-M and blaOXY/K1 b-lactamase genes in Enterobacteriaceae by sequencing of universal M13-sequence tagged PCRamplicons. BMC Infect. Dis. 9, 1-8.

NAWAZ, M., KHAN, A.A., KHAN, S., SUNG, K. and STEELE, R. 2008. Isolation and characterization of tetracycline-resistant Citrobacter spp. from catfish. Food Microbiol. 25, 85-91.

NCCLS 2005. National Committee for Clinical Laboratory Standards. Performance standard for antimicrobial susceptibility testing (Suppl M100S15). Wayne, PA, USA.

PARTRIDGE, S.R. and HALL, R.M. 2005. Evolution of transposons containing blaTEM genes. Antimicrob. Agents Chemother. 49, 1267-1268.

PHILLIPS, I., CASEWELL, M., COX, T., DE GROOT, B., FRIIS, C., JONES, R., NIGHTINGALE, C., PRESTON, R. and WADDELL, J. 2004. Does the use of antibiotics in food animals pose a risk to human health? Acritical review of published data. J. Antimicrob. Chemother. 53, 28-52.

PITCHER, D.G., SAUNDERS, N.A. and OWEN, R.J. 1989. Rapid extraction of bacterial genomic DNA with guanidium thiocyanate. Lett. Appl. Microbiol. 8, 151-156.

PRATS, G., MIRELIS, B., MIRÓ, E., NAVARRO, F., LlOVET, T., JOHNSON, J.R., CAMPS, N., DOMÍNGUEZ, A. and SALLERAS, L. 2003. Cephalosporin-resistant Escherichia coli among summer camp attendees with salmonellosis. Emerg Infect Dis. 9, 1273-1280.

SCHMITT, J., JACOBS, E. and SCHMIDT, H. 2007. Molecular characterization of extended-spectrum beta-lactamases in Enterobacteriaceae from patients of two hospitals in Saxony, Germany. J. Med. Microbiol. 56, 241-249.

SHAH, A.A., HASAN, F., AHMED, S. and HAMEED, A. 2004. Characteristics, epidemiology and clinical importance of emerging strains of 
Gram-negative bacilli producing extended-spectrum b-lactamases. Res. Microbiol. 155, 409-421.

SILBERGELD, E.K., GRAHAM, J. and PRICE, L.B. 2008. Industrial food animal production, antimicrobial resistance, and human health. Annu. Rev. Public Health 29, 151-169.

SIMEONI, D., RIZZOTTI, L., COCCONCELLI, P., GAZZOLA, S., DELLAGLIO, F. and TORRIANI, S. 2008. Antibiotic resistance genes and identification of staphylococci collected from the production chain of swine meat commodities. Food Microbiol. 25, 196-201.

SLAMA, T.G. 2008. Gram-negative antibiotic resistance: there is a price to pay. Crit. Care 12(Suppl 4), 1-7.

SMET, A., MARTEL, A., PERSOONS, D., DEWULF, J., HEYNDRICKX, M., CATRY, B., HERMAN, L., HAESEBROUCK, F. and BUTAYE, P. 2008. Diversity of extended-spectrum b-lactamases and class C blactamases among cloacal Escherichia coli isolates in Belgian broiler farms. Antimicrob. Agents Chemother. 52, 1238-1243.

STINE, O.C., JOHNSON, J.A., KEEFER-NORRIS, A., PERRY, K.L., TIGNO, J., QAIYUMI, S., STINE, M.S. and MORRIS, J.G., JR 2007. Widespread distribution of tetracycline resistance genes in a confined animal feeding facility. Int J Antimicrob Agents. 29, 348-352.

SUNDE, M., THARALDSEN, H., SLETTEMEÅS, J.S., NORSTRÖM, M., CARATTOLI, A. and BJORLAND, J. 2009. Escherichia coli of animal origin in Norway contain a blaTEM-20-carrying plasmid closely related to blaTEM-20 and blaTEM-52 plasmids from other European countries. J. Antimicrob. Chemother. 63, 215-216.

WANG, H.H., MANUZON, M., LEHMAN, M., WAN, K., LUO, H., WITTUM, T.E., YOUSEF, A. and BAKALETZ, L.O. 2005. Food commensal microbes as a potentially important avenue in transmitting antibiotic resistance genes. FEMS Microbiol. Lett. 254, 226-231.

WHO 2000. World Health Organization. Global Principles for the Containment of Antimicrobial Resistance in Animals Intended for Food. Geneve, Switzerland.

WU, S.W., DORNBUSCH, K. and KRONVALL, G. 1999. Genetic characterization of resistance to extended-spectrum beta-lactams in Klebsiella oxytoca isolates recovered from patients with septicemia at hospitals in the Stockholm area. Antimicrob. Agents Chemother. 43, 1294-1297.

YUAN, L., LIU, J.H., HU, G.Z., PAN, Y.S., LIU, Z.M., MO, J. and WEI, Y.J. 2009. Molecular characterization of extended-spectrum-beta-lactamaseproducing Escherichia coli isolates from chickens in Henan Province of China. J. Med. Microbiol. [Epub 2009 Jul 2]. 